\title{
TANTANGAN BAGI PERPUSTAKAAN DAN PUSTAKAWAN DI ERA REVOLUSI INDUSTRI 4.0
}

\author{
Fitria Nurhaliza Lubis, Marlini \\ Program Studi Perpustakaan dan Ilmu Informasi \\ FBS Universitas Negeri Padang \\ e-mail: liza.14278@gmail.com
}

\begin{abstract}
Abstrak
Perpustakaan memiliki peran yang sangat penting sebagai sumber pengetahuan. Era 4.0 merupakan era revolusi industri yang mana akan merubah pola berpikir dan kerja seseorang. Semakin berkembangnya teknologi, perpustakaan juga harus mengikuti perkembangan tersebut agar tidak tertinggal sehingga membuat perpustakaan dijauhi oleh pemustaka. Dalam menghadapi era revolusi industri 4.0 ini tidak hanya perpustakaan yang harus maju dan berkembang tetapi, pustakawan yang juga memiliki peran penting di perpustakaan harus mengikuti perkembangan teknologi, karena pustakawan memiliki peran untuk mencarikan jalan keluar bagi pemustaka saat menghadapi masalah dalam mencari informasi. Semakin berkembangnya jaman, sangat dibutuhkannya literasi terhadap informasi, karena semakin berkembang teknologi informasi maka akan semakin banyak informasi yang tidak sesuai dengan faktanya tau hoax untuk itu diperlukannya literasi informasi.
\end{abstract}

Kata Kunci : Perpustakaan, Pustakawan dan Literasi

\begin{abstract}
Libraries have a very important role as a source of knowledge. Era 4.0 is an industrial revolution era which will change one's thinking and work patterns. As technology develops, libraries must also keep up with these developments so as not to be left behind so that libraries are shunned by users. In facing the era of the industrial revolution 4.0, not only libraries must advance and develop, but librarians who also have an important role in libraries must keep up with technological developments, because librarians have a role to find solutions for users when they face problems in finding information. The more developing times, information literacy is very much needed, because the more information technology develops, the more information that is not in accordance with the facts, or hoaxes, is necessary for information literacy.
\end{abstract}

Keyword : Library, Librarian and Literacy 


\section{A. PENDAhUluan}

Kemajuan teknologi informasi dan komunikasi telah membawa perubahan yang luar biasa bagi masyarakat, dan teknologi telah memberikan banyak kemudahan dalam melakukan segala hal. Kemajuan semacam ini cenderung mempengaruhi gaya hidup masyarakat yang menginginkan segala sesuatu secara cepat dan instan. Permintaan akan informasi publik terus berkembang, bahkan masyarakat dapat memperoleh informasi ini dengan cepat, mudah, dan praktis tanpa meninggalkan tempat duduknya. Sebagai penyedia informasi, perpustakaan harus memperhatikan hal ini.

Perpustakaan merupakan tempat mengumpulkan, mengelola dan melayani pemustaka, serta dapat menyediakan informasi terkini sesuai dengan perkembangan ilmu pengetahuan dan teknologi. Perpustakaan pada saat ini tidak hanya dapat dipahami sebagai sebuah gedung tempat menyimpan banyak buku yang berdebu dan membosankan. Namun tergantung dari jenis perpustakaannya (perpustakaan perguruan tinggi, perpustakaan sekolah, perpustakaan khusus, dsb) yang dapat diartikan sebagai satu unit kerja dengan sumber daya manusia dan koleksinya. Ditambah dengan semakin berkembangnya teknologi yang mana memberikan kemudahan dan cepat dalam menemukan informasi. Perpustakaan yang mengikuti perkembang tersebut akan membuat daya tarik perpustakaan meningkat dan membuat pemustaka ingin datang dan berlama-lama di perpustakaan untuk mencari informasi yang dibutuhkannya.

Di era 4.0 ini seorang pustakawan harus berani menerima tantangan, sehingga pustakawan tidak tertinggal perkembangan dan tidak ditinggalkan oleh pemustakanya. Apabila seorang pustakawan tidak menguasai teknologi tersebut maka, hal ini mengakibatkan ia akan ditinggalkan oleh pemustaka dan pemustaka tersebut akan beralih ke perpustakaan lain yang mana pustakawannya menguasai teknologi tersebut dan pastinya layanannya lebih maju. 
Kelengkapan fasilitas, perlengkapan, dan koleksi buku sangat ditentukan oleh era teknologi yang semakin modern, sehingga perlu mengajak pustakawan untuk lebih mengenal teknologi modern. Ini tujuannya agar pustakawan tidak merasa malu dan awam dengan teknologi modern yang disediakan. Pustakawan yang percaya diri dalam menggunakan teknologi dalam sistem kerjanya harus memiliki tanggung jawab profesional. Selain itu, pustakawan didorong untuk mengikuti seminar dan pelatihan terkait perkembangan teknologi dan informasi untuk meningkatkan pengetahuan dan keterampilannya.

Literasi informasi sangat dibutuhkan karena mampu mempengaruhi masyarakat untuk menyikapi fenomena banjir informasi dan ledakan informasi pada saat sekarang ini. Kemampuan literasi informasi ini dapat menjadi modal bagi masyarakat dalam menyikapinya sehingga masyarakat dapat lebih memahami dan tidak akan terombang ambing oleh informasi yang negative dan tidak jelas. Selain itu juga dapat menghindarkan masyarakat dari berita- berita hoax atau hasutan dari informasi dunia maya atau media social.

Kekuatan komunikasi massa tidak ada tandingannya. Isi pesan media massa sangat halus sehingga tidak disadari khususnya oleh generasi muda, mendorong munculnya kebutuhan akan literasi media. Literasi media adalah kemampuan seseorang untuk mengakses, menganalisis, mengevaluasi, dan mengkomunikasikan isi pesan media. Kegiatan literasi media lebih didorong oleh kekhawatiran tentang kemungkinan efek negatif dari media. Oleh karena itu, masyarakat diharapkan dapat mengikuti perkembangan zaman agar tidak kehilangan informasi, tetapi disertai dengan literasi informasi.

\section{B. Metode Penelitian}

Jenis penelitian pada artikel ini studi literature. Pengumpulan data dilakukan dengan mengamati dan mengambil data dari beberapa literature seperti buku, artikel dan jurnal. 


\section{PEMBahasan}

\section{Perpustakaan di Era 4.0}

Perpustakaan berasal dari bahasa inggris yaitu "library", yang berasal dari kata "libri" yang artinya pustaka, buku ataupun kitab. Perpustakaan menurut Undang-Undang RI Nomor 43 Tahun 2007 tentang perpustakaan, perpustakaan adalah institusi pengelola koleksi karya tulis, cetak ataupun karya rekam secara professional dengan menggunakan system yang baku untuk memenuhi kebutuhan informasi, penelitian, pelestarian, pendidikan dan rekreasi bagi pemustaka. Sedangkan menurut pendapat Sulistyo-Basuki (1993: 3), perpustakaan adalah sebuah gedung yang dipergunakan untuk menyimpan buku dan terbitan lainnya yang biasanya di simpan berdasarkan susunan tertentu yang akan digunakan oleh pembaca, dan bukan untuk dijual. (Ii \& Perpustakaan, 2007)

Mengikuti perkembangan jaman saat sekarang ini, perpustakaan tentunya harus berkembang mengikuti jaman dan teknologi. Perpustakaan yang awalnya hanya sekedar gedung yang menyediakan informasi dengan bentuk buku-buku tebal, tetapi seiring dengan perkembangan jaman telah berubah dengan adanya berbagai bentuk media komunikasi tidak hanya tulisan tetapi ada yang berbentu rekaman dan elektronik. Tetapi untuk mengukur image baik dan buruknya tidak hanya ditentukan dari gedung dan koleksinya saja tetapi juga dilihat dari kinerja seorang pustakawannya.

Pada umumnya sebagian besar koleksi buku atau informasi yang ada di perpustakaan berbentuk cetak dengan bahan kertas. Apabila tidak dilakukan pemeliharaan secara rutin terhadap koleksi buku tersebut maka akan mengakibatkan kerusakan buku baik fisik, informasi maupun ilmu yang ada dibuku tersebut. Pada era perkembangan teknologi informasi saat ini, perpustakaan harus bisa mengikuti perkembangan tersebut yang mana bisa memberikan layanan penyediaan informasi yang cepat, tepat dan real time kepada pemustaka. Hal tersebut dapat tercapai dengan memanfaatkan fasilitas computer, 
jaringan internet dan koleksi buku perpustakaan sudah dialih bentuk kedalam bentuk digital.

Perubahan bentuk koleksi perpustakaan adalah merubah bentuk koleksi perpustakaan yang awalnya hanya berbentuk buku cetak dengan berbahan kertas dikembangkan menjadi koleksi yang digital. Hal ini bertujuan untuk melestarikan nilai informasi termasuk koleksi informasi yang efisiensi ruang penyimpanan, memperbanyak jumlah dan keragaman koleksi informasi, kecepatan dalam temu kembali informasi, tukar menukar informasi antara perpustakaan, penggunaan koleksi bersama dan memudahkan penyebaran informasi kepada pengguna.

Di era 4.0 menuntut perpustakaan untuk melengkapi sarana dan fasilitas didalam penyediaan sumber - sumber informasi dan sebagai daya tarik yang ditujukan untuk pemustaka yang memanfaatkan koleksi perpustakaan untuk memnuhi kebutuhan informasi baik itu tentang perkembangan ilmu pengetahuan maupun teknologi. (Wijaya \& Riyana, 2016)

Pada umumnya masyarakat mengetahui bahwa perpustakaan hanya memiliki sumber informasi dalam bentuk cetak. Tetapi pada era perkembangan teknologi informasi sekarang ini, informasi yang awalnya hanya berbentuk cetak sekarang sudah ada yang berbentuk digital. Perpustakaan yang awalnya dalam pelayanan, penyimpanan dan penyajian informasi secara manual saat sekarang ini sudah berubah dalam bentuk digital atau elektronik. Dampaknya pun sangat dirasakan karena semakin cepat dan lebih mudah untuk ditemukan kembali. Seiring dengan perkembangan jaman,teknologi informasi pun juga semakin berkembang.

OPAC (Online Public Access Catalogue) merupakan catalog digital yang digunakan untuk membantu menelusuri koleksi buku di perpustakaan oleh pemustaka menjadi lebih mudah. Dalam penggunaan OPAC tidak semua pemustaka mau dan mampu menggunakan OPAC dalam penelusuran data-data koleksi yang ingin ditelusuri saat berada di perpustakaan. Dalam penggunaan OPAC, hal yang paling utama 
mempengaruhi hasil dalam proses pencarian adalah kata kunci (keyword). Kata kunci akan menentukan hasil dalam proses pencarian yang dilakukan oleh pemustaka. Kata kunci sendiri terdiri dari judul buku, nama pengarang dan subjek.

Setelah menemukan judul buku yang dibutuhkan pada proses pencarian menggunakan kata kunci pada OPAC, langkah selanjutnya pun adalah mulai mencari koleksi buku yang dicari di rak. OPAC juga bisa digunakan sebagai saran untuk memeriksa status bahan pustaka. Adapun kendala yang dialami oleh pemustaka saat menggunakan OPAC, setelah menggunakan OPAC pemustaka kesulitan dalam mencari koleksi buku yang terletak di rak, yang kemungkin karena tidak memahami bahasa atau kode yang dimaksud OPAC. Yang mana OPAC memiliki bahasa sendiri untuk kata atau istilah spesifik yang sulit dipahami oleh pemustaka.

Adapun koleksi buku dengan nama pengarang yang sama namun judulnya berbeda. Sehingga untuk menemukan koleksi buku pada OPAC diperlukan ke kreatifan untuk memasukan kata kunci (keyword) judul buku yang diinginkan agar sesuai dengan judul-judul yang di informasikan oleh OPAC. Penelusuran koleksi melalui OPAC dapat membantu meningkatkan produktifitas pengguna dalam teknik menggunakan keyword untuk menemukan judul yang diinginkan namun sesuai dengan judul yang tertera pada OPAC. OPAC merupakan suatu system inoformasi yang deprogram unutk digunakan sebagai katalog. Maka penilaian baik atau tidaknya OPAC tergantung pemustaka dalam menggunakannya. Penggunaan OPAC akan terasa mudah dalam penelusuran apabilan tampilannya jelas, tidak ribet dan cukup menarik. Dari berbagai bentuk katalog yang ada di perpustakaan, OPAC merupakan katalog yang paling fleksibel dan paling mudah untuk digunakan karena efektif dan efisien.

\section{Pustakawan di Era 4.0}


Pustakawan adalah sumber daya manusia (SDM) pengelola perpustakaan dan pustakawan penanggung jawab perpustakaan. Pustakawan adalah sebuah profesi, karena pustakawan adalah pekerjaan yang membutuhkan pendidikan atau pelatihan.(Wahyuni, 2015)

Pustakawan yang hidup di era digital tidak hanya memiliki keterampilan, tetapi juga memiliki pengetahuan sosial yang tinggi, perkembangan sosial saat ini terus berkembang yaitu revolisi industri 4.0, dan banyak negara termasuk Indonesia juga gencar bersosialisasi. Untuk revolusi industri 4.0 yang juga merambah lingkup kegiatan perpustakaan, pustakawan harus siap menghadapi perubahan jaman, yaitu pustakawan harus memenuhi standar kompetensi profesional.

Dalam perkembangan teknologi saat ini, pustakawan harus memiliki keberanian yang cukup untuk menerima tantangan tersebut, sehingga pustakawan tidak akan ketinggalan, juga tidak akan tertinggal. Jika pustakawan tidak menguasai teknologinya maka akan menyebabkan dia ditinggalkan oleh pustakawan, dan pengguna perpustakaan akan beralih ke perpustakaan lain, dimana pustakawan menguasai teknologi tersebut, dan tentunya pelayanan akan lebih maju. Menurut (Ilmiah, 2015), Pustakawan harus memiliki prinsip-prinsip sebagai berikut:

1. Skill, yang mana seorang pustakawan dituntut untuk mempunyai kecakapan, keterampilan, dan kepandaian dalam bidang teknologi dan informasi.

2. Knowledge, seorang pustakawan harus mempunyai pengetahuan, wawasan yang luas, dan keingintahuan yang lebih dalam bidang teknologi dan informasi.

3. Ability, seorang pustakawan harus memiliki kecakapan dan kemampuan dalam memberikan pelayanan kepada pemustaka yang datang.

4. Kedewasaan psikologis, seorang pustakawan harus memiliki keprofesionalitas yang tinggi yang berkaitan dengan perkembangan teknologi dan informasi saat ini. 
Pustakawan tidak hanya berurusan dengan benda mati seperti dokumen, buku, komputer dan benda lainnya. Pustakawan juga harus menjalin kontak dengan orang lain di lingkungan kerjanya yaitu hubungan antar pengguna, atasan, bawahan dan pustakawan. Dalam hubungan sosial ini kepribadian berkembang terus menerus dan dipengaruhi oleh lingkungan. Untuk mengembangkan hubungan tersebut, pustakawan hendaknya menjalin hubungan interpersonal yang baik dengan masyarakat di lingkungan perpustakaan.

\section{Literasi Informasi dan Media di Era 4.0}

Literasi media adalah kemampuan menggunakan berbagai media untuk mengakses, menganalisis, dan memproduksi berbagai media dalam kehidupan sehari-hari masyarakat yang akan dipengaruhi oleh media di sekitar kita melalui radio, televisi, rekaman, surat kabar, majalah dan film. Informasi tujuan. Perkembangan media tidak terlepas dari ilmu komunikasi. Tujuan dasar ilmu komunikasi adalah untuk menyampaikan informasi, karena pada dasarnya fungsi media adalah menyampaikan informasi kepada masyarakat luas. Secara umum, media massa merupakan alat komunikasi yang secara simultan dan cepat dapat menyebarkan informasi kepada penerima informasi dalam jumlah besar. (Bergan \& Lee, 2018)

Perpustakaan memainkan peran utama dalam informasi karena perpustakaan menyediakan layanan untuk membantu pengguna mengevaluasi dan menggunakan informasi untuk menambah pengetahuan. Di era digital seperti sekarang ini, perpustakaan mengubah layanannya menjadi layanan digital seiring dengan perkembangan zaman. Pengguna menunjukkan kebutuhan dan perilaku baru yang mengubah dinamika hubungan mereka dengan teknologi. Perpustakaan muncul dalam situasi ini karena menghubungkan aktivitas pustakawan yang sebelumnya manual dan sekarang digital. Era digital membuat informasi menjadi fleksibel, sehingga dapat diatur dan dibagikan dalam berbagai bentuk. (Ottonicar et al., 2018) 
Literasi informasi merupakan keterampilan yang harus dimiliki setiap masyarakat di era banjir informasi saat ini. Literasi informasi membutuhkan keterampilan berpikir kritis masyarakat dan kemauan untuk terus belajar. Proses ini tidak akan pernah berhenti. Artinya, setiap anggota masyarakat perlu memiliki pemahaman yang mendalam tentang literasi informasi. Pesatnya perkembangan teknologi informasi dan komunikasi tidak selalu memudahkan masyarakat. Banyaknya informasi yang dapat diakses melalui Internet menimbulkan pertanyaan bagi pengguna. Sesuatu yang dapat dilakukan oleh perpustakaan yaitu dengan memberikan pendidikan kepada pemustaka, dan focus pada pengembangan literasi pemustaka. Pustakawan dapat mengajarkan literasi informasi melalui pendidikan pengguna perpustakaan.

Kemajuan teknologi informasi merupakan salah satu pendorong utama lahirnya perpustakaan digital. Perpustakaan digital sadar akan perubahan cara mereka mengelola sumber informasi. Namun keberadaan perpustakaan digital tidak bisa sepenuhnya mengubah atau menghilangkan kebiasaan pustakawan yang sudah lama ada.

Saat ini perpustakaan menghadapi tantangan yang sangat besar, yaitu mengikuti perkembangan zaman, yaitu era teknologi komputer, internet dan lingkungan digital. Perubahan lingkungan digital telah mengubah perilaku orang dalam mengakses informasi. Banyak orang yang tampak enggan datang ke perpustakaan karena merasa kebutuhan informasinya telah terpenuhi melalui internet. Ini harus mendorong perpustakaan untuk beradaptasi dengan lingkungan serba digital yang selalu berubah ini. Di era digital saat ini, pengaruh media cetak seperti buku dan keberadaannya di perpustakaan memegang peranan yang sangat penting karena dapat bertahan lama dan dapat dibaca berulang kali. Penggunaan media dapat merangsang perilaku positif dari penggunaan Untuk tujuan motivasi penggunaan media meliputi tujuan mempengaruhi sikap, nilai, dan emosi. Media audiovisual seperti film dan video dapat menggugah emosi orang, menghargai nilai, dan menanamkan sikap tertentu. 
Perpustakaan harus menyediakan layanan media untuk tujuan pengajaran. Desain media yang ada harus memungkinkan pengguna untuk memiliki pengalaman belajar yang baru dan menyenangkan. Media memungkinkan pemakainya mengatasi kendala berupa ruang dan waktu guna memperoleh informasi dan pengetahuan. Oleh karena itu keberadaan media di perpustakaan sangat membantu pengguna untuk memperoleh informasi yang dibutuhkan.

\section{KESIMPULAN}

Kemajuan teknologi informasi dan komunikasi telah membawa perubahan yang luar biasa bagi masyarakat, dan teknologi telah memberikan banyak kemudahan untuk segala hal. Mengubah bentuk koleksi perpustakaan, yang semula berupa berbentuk buku cetak berbasis kertas, kemudian berkembang menjadi koleksi digital. OPAC merupakan katalog digital yang digunakan untuk memudahkan pengguna dalam menelusuri buku-buku di perpustakaan. Dalam perkembangan teknologi saat ini, pustakawan harus memiliki keberanian yang cukup untuk menerima tantangan tersebut, sehingga pustakawan tidak akan ketinggalan, juga tidak akan ketinggalan. Literasi informasi membutuhkan keterampilan berpikir kritis masyarakat dan kemauan untuk terus belajar. Proses ini tidak akan pernah berhenti. Artinya, setiap anggota masyarakat perlu memiliki pemahaman yang mendalam tentang literasi informasi. 


\section{DAFTAR PUSTAKA}

Bergan, D., \& Lee, H. (2018). Media Literacy and Response to Terror News. Journal of Media Literacy Education, 10(3), 43-56. https://doi.org/10.23860/jmle-2018-10-3-3

Ii, B. A. B., \& Perpustakaan, P. (2007). BAB II TINJAUAN LITERATUR 2.1 Pengertian Perpustakaan. 9-22.

Ilmiah, P. (2015). Pustaka Ilmiah. 1(1).

Ottonicar, S. L. C., da Silva, R. C., \& Barboza, E. L. (2018). The contributions of information and media literacy to public hybrid libraries. Library Quarterly, 88(3), 225-236. https: / / doi.org/10.1086/697703

Wahyuni, M. (2015). PERAN PUSTAKAWAN SEBAGAI PENYEDIA INFORMASI Oleh: Mutiara Wahyuni. Iqra, Jurnal, 09(02), 39-53. http://jurnal.uinsu.ac.id/index.php/iqra/article/viewFile/73/225

Wijaya, A., \& Riyana, C. (2016). Pemanfaatan Internet Pada Perpustakaan Daerah. Edulib, 3(2). https://doi.org/10.17509/edulib.v3i2.4156 